\title{
Nitrogen supply method affects growth, yield and must composition of young grape vines (Vitis vinifera L. cv Alicante Bouschet) in southern Brazil
}

\author{
Lincon Oliveira Stefanello ${ }^{\mathrm{a}}$, Raíssa Schwalbert ${ }^{\mathrm{b}}$, Raí Augusto Schwalbert ${ }^{\mathrm{c}}$, Lessandro De Conti ${ }^{\mathrm{d}}$, \\ Matheus Severo de Souza Kulmann ${ }^{\mathrm{a}}$, Luana Paula Garlet ${ }^{\mathrm{a}}$, Marcia Liliane Rippel Silveira ${ }^{\mathrm{e}}$, \\ Cláudia Kaehler Sautter ${ }^{\mathrm{e}}$, George Wellington Bastos de Melo ${ }^{\mathrm{f}}$, Danilo Eduardo Rozane ${ }^{\mathrm{g}}$, \\ Gustavo Brunetto ${ }^{a, *}$
}

a Soil Science Department of Federal University of Santa Maria (UFSM), 97105-900, Santa Maria, RS, Brazil

${ }^{\mathrm{b}}$ Agronomy Department of Federal University of Santa Maria (UFSM), 97105-900, Santa Maria, RS, Brazil

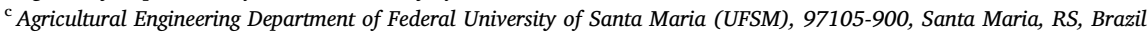

${ }^{\mathrm{d}}$ Federal Institute Farroupilha, Santo Augusto Campus, 98590-000, Santo Augusto, RS, Brazil

${ }^{\mathrm{e}}$ Food Technology Department of Federal University of Santa Maria (UFSM), 97105-900, Santa Maria, RS, Brazil

${ }^{\mathrm{f}}$ National Research Center of Grape and Wine, Brazilian Agricultural Research Corporation (Embrapa), 95700-000, Bento Gonçalves, RS, Brazil

${ }^{\mathrm{g}}$ Fruticulture Department of Paulista State University, 11900-000, Registro, SP, Brazil

A R T I C L E I N F O

\section{Keywords:}

Nitrogen fertilization

Nitrogen fertigation

Leaf $\mathrm{N}$ concentration

Anthocyanins

Field study

Long-term

\begin{abstract}
A B S T R A C T
The aim of this study was to evaluate yield and chemical composition of the must in grapevines subjected to Nitrogen (N) supply methods in sandy soils. The vineyard cultivar was 'Alicante Bouschet' (Vitis vinifera L.) grafted on 1103 Paulsen rootstock, in southern Brazil. The treatments consisted of the application of $20+20 \mathrm{~kg} \mathrm{~N} \mathrm{ha}^{-1}$ without irrigation (NWI), $20+20 \mathrm{~kg} \mathrm{~N}^{-1}$ followed by irrigation (NFI), $20+20 \mathrm{~kg} \mathrm{~N} \mathrm{ha}^{-1}$ via fertigation (NF), $20 \mathrm{~kg} \mathrm{~N} \mathrm{ha}^{-1}$ via fertigation $(1 / 2 \mathrm{NF})$, and a control (C) without $\mathrm{N}$ application. The study was conducted during four crop seasons. Leaves were collected at flowering and veraison to determination $\mathrm{N}$ concentration. Stem diameter, grape yield and its components were determined. In the must were evaluated the total soluble solids (TSS), pH, total titratable acidity (TTA) and total anthocyanins (TA). The concentration of nitrate and ammonium in soil solution was determined. $\mathrm{N}$ application followed by irrigation or $\mathrm{N}$ supplied via fertigation provided to the vines larger stem diameters and leaf $\mathrm{N}$ concentrations, in most crop seasons. Grapevines submitted to $\mathrm{N}$ application via fertigation or followed by irrigation presented higher yields than conventional application without irrigation, and between two and three times higher than the control. N supply methods little affected total soluble solids contents. The application of $\mathrm{N}$ to the soil, regardless of the $\mathrm{N}$ supply method, decreased the anthocyanin concentration in the grape must, due to the dilution effect on the pulp/skin ratio, promoted by the yield increase.
\end{abstract}

\section{Introduction}

The expansion of agricultural frontiers in Brazil starting from the green revolution, which occurred especially over large areas previously used for cattle raising, allowed the establishment of grapevines in regions such as Campanha Gaúcha, in the southern region of the country. In this region, there is a predominance of spontaneous native species of the Pampa Biome. This Biome covers a large area of other countries such as Uruguay and Argentina (De Conti et al., 2019). The development of viticulture in the region was intensified by some characteristics, such as the ease of natural field conversion into vineyards areas, the possibility of mechanization in management practices which allows a large scale productive potential, and the favorable climatic conditions (Flores and Medeiros, 2013). According to data generated by the Brazilian Wine Institute (Ibravin), approximately 614 million kilos of grapes were produced during the 2018/19 harvest in the Rio Grande do Sul state, which is consolidated as the largest producer of grapes, wines and sparkling wines in the country. However, grapevines are generally cultivated in sandy soils with low organic matter (SOM) content, which results in low soil nitrogen $(\mathrm{N})$ availability. Thus, in order to achieve adequate yields of grapevines, it is necessary to the $\mathrm{N}$ supply physiological demand of the plants by applying $\mathrm{N}$ sources (Brunetto et al.,

\footnotetext{
* Corresponding author.

E-mail address: brunetto.gustavo@gmail.com (G. Brunetto).
} 
2016).

Sandy soils with low organic matter do not typically meet nitrogen (N) demand of grapevines. This can be diagnosed by low tissue $\mathrm{N}$ concentration and decreased yield. An alternative to remedy this situation is the use of $\mathrm{N}$ sources such as urea, because of its lower cost per unit of N (Queiroz et al., 2011). Doses of N (as urea) are typically applied on the soil surface without incorporation to avoid physical damages to the root system, which could stimulate the incidence of diseases in the roots, especially in countries of subtropical climate, where rainfall is frequent and temperatures are higher (Steenwerth and Belina, 2010).

Urea applied to the soil is rapidly hydrolyzed by ureases, producing ammonium carbonate $\left(\mathrm{NH}_{4}\right)_{2} \mathrm{CO}_{3}$. When water is involved, part of this compound will be decomposed into bicarbonate $\left(\mathrm{HCO}_{3}{ }^{-}\right)$, hydroxyl $\left(\mathrm{OH}^{-}\right)$, and ammonium $\left(\mathrm{NH}_{4}{ }^{+}\right)$. Bicarbonate can decompose in carbon dioxide $\left(\mathrm{CO}_{2}\right)$ and hydroxyl, and if ammonium reacts with hydroxyl, there will be loss of ammonia $\left(\mathrm{NH}_{3}\right)$ to the atmosphere. This may explain the small use of $\mathrm{N}$ by the grapevines, especially when applied to the soil surface (Brunetto et al., 2016), thus decreasing yield (PérezÁlvarez et al., 2013). Therefore, alternative modes of $\mathrm{N}$ application such as fertigation or the application of $\mathrm{N}$ followed by irrigation are necessary, because they may be able to provide a better use of $\mathrm{N}$ by the grapevines.

Irrigation or fertigation water can accelerate the solubility of urea and the infiltration of ammonium and nitrate in the soil profile to regions with higher root presence, improving the uptake of mineral $\mathrm{N}$ forms (Barlow et al., 2009). Therefore, lower migration of nitrate along the soil profile is expected, especially in more sandy soils with low organic matter, and this may decrease the contamination of subsurface waters (Castellanos et al., 2013). Nitrogen absorbed by the roots of the grapevines can be diagnosed in leaves at flowering or veraison (Arrobas et al., 2014). However, a lower concentration of $\mathrm{N}$ in leaves is expected at veraison, because of the dilution and/or degradation of nitrogenous compounds, followed by the redistribution of $\mathrm{N}$ to growing organs, such as branches of the year and clusters, which act as nutrient sinks (Metay et al., 2015).

The increase of $\mathrm{N}$ within plants may increase the vigor of young grapevines, which can be diagnosed by stem diameter (Fang et al., 2013). It may also increase the number of clusters per plant and grape yield. However, $\mathrm{N}$ management may result in the dilution of total soluble solids (TSS) and total anthocyanins (TA), and also increase total titratable acidity in the must (Kelly et al., 2017; Tarara et al., 2008). The ideal composition of the must and wine are constantly sought by technicians and winemakers in traditional grape-producing countries, focusing on adequate nutrition of the grapevine without depreciating the final product, which increases the likelihood of consumer acceptance. Thus, the concentration of TA has a strong positive correlation with the price of wine (Webb et al., 2006). This is potentiated in 'Alicante Bouschet' (Vitis vinifera L.), whose grape is used in mixing with other cultivars, as it provides greater intensity in the coloring of the wine. This study aimed to evaluate yield and chemical composition of the must in young grapevines subjected to $\mathrm{N}$ application without irrigation, followed by irrigation and via fertigation.

\section{Material and methods}

\subsection{Experimental area description}

The study was conducted in the city of Santana do Livramento (Latitude $30^{\circ} 48^{\prime} 31^{\prime \prime} \mathrm{S}$; Longitude $55^{\circ} 22^{\prime} 33^{\prime \prime} \mathrm{W}$ ) located in the Campanha Gaúcha region of the state of Rio Grande do Sul (RS), southern Brazil. The experimental period was from September 2013 to March 2017. The cultivar 'Alicante Bouschet' (Vitis vinifera L.) was grafted on 1103 Paulsen rootstock and installed in a spacing of $2.8 \mathrm{~m}$ between rows and $1.2 \mathrm{~m}$ between plants (plant density of 2976 plants per hectare). The conduction system of the vines was espalier in double string on the first thread. In the winter pruning of the 2013/14, 2014/ $15,2015 / 16$ and 2016/17 crop seasons, the same number of buds were maintained for all treatments. The topography of the area was characterized as slightly undulating. According to Köppen climate classification, the climate of the region is humid subtropical (Cfa), characterized by mild temperatures and precipitation with little variation throughout the year. The vegetation on the planting rows was annually desiccated with 2 liters ha ${ }^{-1}$ of non-selective systemic herbicide (a.i. glyphosate), with 2 to 4 sequential applications, depending on vegetation growth. Glyphosate was applied mechanically with a directed sprayer. The vegetation between the rows, composed mainly of Paspalum notatum, Paspalum plicatulum, and Lolium multiflorum was mechanically mowed at $10 \mathrm{~cm}$ from the soil, approximately 5 times throughout the cycle of the grapevine. Cover crop residues were placed on the soil surface, between the planting rows.

The soil was classified as Typic Hapludalf (Soil Survey Staff, 2014). At the installation of the experiment, the soil had the following characteristics: $822 \mathrm{~g} \mathrm{~kg}^{-1}$ sand, $115 \mathrm{~g} \mathrm{~kg}^{-1}$ silt and $63 \mathrm{~g} \mathrm{~kg}^{-1}$ clay (Embrapa, 1997); $11 \mathrm{~g} \mathrm{~kg}^{-1}$ organic matter (Walkley-Black method), $5.5 \mathrm{pH}$ in water (1:1 ratio); 25 and $72 \mathrm{mg} \mathrm{kg}^{-1}$ available $\mathrm{P}$ and $\mathrm{K}$, respectively (both extracted by Mehlich-1); 0.0, 1.99 and $0.923 \mathrm{cmol}_{\mathrm{c}}$ $\mathrm{dm}^{-3}$ exchangeable $\mathrm{Al}, \mathrm{Ca}$ and $\mathrm{Mg}$, respectively (extracted by $\mathrm{KCl} 1 \mathrm{~mol}$ $\mathrm{L}^{-1}$ ) (Tedesco et al., 1995). Prior to the installation of the experiment, the vineyard was subjected to an application of approximately $45 \mathrm{~kg}$ $\mathrm{P}_{2} \mathrm{O}_{5} \mathrm{ha}^{-1}$ and $45 \mathrm{~kg} \mathrm{~K}_{2} \mathrm{O} \mathrm{ha}^{-1}$. Triple superphosphate $(41 \% \mathrm{P})$ was the $\mathrm{P}$ source and $\mathrm{KCl}(60 \% \mathrm{~K})$ was the $\mathrm{K}$ source.

\subsection{Treatments}

The experimental design was randomized blocks with five replicates. Each replicate consisted of five plants and the three central plants were evaluated. The treatments were nitrogen supply modes annually application during of period budding (September/October). The first $\mathrm{N}$ application was realized at 14 days after the start of budding, and 20 days thereafter was realized the second $\mathrm{N}$ application. The fractionation of the $\mathrm{N}$ applications aimed to reduce the losses by volatilization, since the grapevines are cultivated on sandy soils. Thus, the treatments were application of $20 \mathrm{~kg} \mathrm{~N} \mathrm{ha}^{-1}+20 \mathrm{~kg} \mathrm{~N}^{-1}$ without irrigation (NWI), $20 \mathrm{~kg} \mathrm{~N} \mathrm{ha}^{-1}+20 \mathrm{~kg} \mathrm{~N} \mathrm{ha}^{-1}$ followed by irrigation (NFI), $20 \mathrm{~kg} \mathrm{~N} \mathrm{ha}^{-1}+20 \mathrm{~kg} \mathrm{~N}$ ha $^{-1}$ via fertigation (NF), $20 \mathrm{~kg} \mathrm{~N}^{-1}$ via fertigation $(1 / 2 \mathrm{NF})$, and a control (C) without $\mathrm{N}$ nor external water application system. The $\mathrm{N}$ source in all treatments was urea $(45 \% \mathrm{~N})$. In treatments with and without irrigation, urea was applied to the soil surface of the planting row, in the canopy projection area. The doses of $20 \mathrm{~kg} \mathrm{~N} \mathrm{ha}^{-1}+20 \mathrm{~kg} \mathrm{~N} \mathrm{ha}^{-1}$ were set based on the technical recommendation for the grapevine proposed by CQFS-RS/SC (2004) for soils with sandy texture and organic matter content lower than and equal to $25 \mathrm{~g} \mathrm{~kg}^{-1}$. The Netafim ${ }^{\mathrm{TM}}$ Dripnet PC AS 16250 drip system was used for irrigation and fertigation, with a flow rate of 1.61 hour and spacing of $0.6 \mathrm{~m}$ between drippers. Fertigation in the NF and $1 / 2 \mathrm{NF}$ treatments were done in four instants, with an interval of five days between applications. The $\mathrm{N}$ application on fertigation occurred in 3 stages during each application: (i) $10 \mathrm{~min}$ with water only, (ii) $10 \mathrm{~min}$ with nitrogen solution, (iii) $10 \mathrm{~min}$ with water only. In the modes in which the water was used during the $\mathrm{N}$ supply process, 1.6 liters of water per plant were supplied to each application. Thus, in the NF and NFI treatments, which consisted of $20 \mathrm{~kg} \mathrm{~N} \mathrm{ha}^{-1}$ (in 4 moments) + $20 \mathrm{~kg} \mathrm{~N}^{-1}$ (4 more times), this totaled 12.8 liters of water per plant per season of culture. Already for the $1 / 2 \mathrm{NF}$ treatment, $20 \mathrm{~kg} \mathrm{~N}^{-1}$ (in 4 moments) was applied, totalizing 6.4 liters of water per plant per crop season. In the NFI treatment, irrigation was done immediately after the application of urea at the soil for $30 \mathrm{~min}$.

\subsection{Leaf collection for $N$ analysis and measuring stem diameter}

At flowering (October/November) and veraison (December/ 
January), we collected six fully-expanded leaves, opposite to the cluster, in the middle third of branches of the year, being that, leaves of the upper or lower of grapevine not were selected. According to CQFSRS/SC (2004), this leaf is the diagnostic organ for assessing the nutritional status of the grapevine. The leaves were washed with distilled water and dried in an oven with forced air circulation at $65^{\circ} \mathrm{C}$ until reaching constant weight. The leaves were then ground in a Wiley-type mill and passed through a $2 \mathrm{~mm}$ mesh sieve. Sulfuric digestion of the leaves was carried out according to the methodology proposed by Tedesco et al. (1995). Total $\mathrm{N}$ was distilled in Kjeldahl semi-micro steam distiller (Tecnal, TE-0363, Brazil) (Tedesco et al., 1995). Stem diameter was measured at $10 \mathrm{~cm}$ from the soil surface with an analog caliper (ZAAS, PAQ6, Brazil) on the same dates the leaves were collected.

\subsection{Collection of soil solution and determination of ammonium and nitrate}

In September 2015, lysimeters with porous capsules were installed in the soil surrounding the three central plants of each plot in all the treatments. This was done at a depth of $0.3 \mathrm{~m}$ in the planting rows, where $\mathrm{N}$ was applied annually. The lysimeters were installed approximately $0.25 \mathrm{~m}$ from the stem of each plant. In each precipitation event after the application of the treatments, a vacuum ( $25 \mathrm{kgf}$ ) was applied using a hand pump. During the productive cycle of the vine in the 2015/16 season there were 10 pluviometric events that made possible the collection of the soil solution. The soil solution was collected on 09/ $23 / 2015,10 / 02 / 2015,10 / 07 / 2015,10 / 13 / 2015,11 / 03 / 2015,11 /$ $17 / 2015,12 / 10 / 2015,01 / 04 / 2016,01 / 12 / 2016$ and $01 / 27 / 2016$. The solution within the lysimeters was removed with a syringe coupled to a hose. The soil solution samples were stored in $80 \mathrm{ml}$ plastic pots and kept in a freezer at $4{ }^{\circ} \mathrm{C}$. Later in the laboratory, concentrations of ammonium and nitrate were determined according to the methodology proposed by Tedesco et al. (1995). To do this, $20 \mathrm{ml}$ of the solution was added in $100 \mathrm{ml}$ distillation tubes.

\subsection{Yield and its components}

At harvesting in 2013/14, 2014/15, 2015/16 and 2016/17, the number of clusters per plant was counted. All the clusters were weighed to determine yield (kg per plant), using a digital scale (Walmur, $50 \mathrm{~K}$, Brazil), with a precision of three digits. Five clusters per plant were reserved. Subsequently, the number of berries was counted in each cluster. Then, they were weighed to determine the weight of 100 berries. Berries of the upper, middle and lower thirds of the clusters were collected, totalizing one hundred berries per replicate, and nine replicates per treatment. The berries were reserved for future chemical analysis of the must and from each replicate was realized laboratory triplicates.

\subsection{Chemical analysis of the must}

The berries reserved for analysis of total soluble solids (TSS), $\mathrm{pH}$ and total titratable acidity (TTA) were peeled and macerated manually, using only pulp with seed. TSS content ( ${ }^{\circ}$ Brix) was determined using a digital refractometer (Atago PAL-3, Japan) according to AOAC (2005) standards. The $\mathrm{pH}$ was measured using a digital benchtop $\mathrm{pH}$ meter at $20^{\circ} \mathrm{C}$ (Digimed DM-22, Brazil). The results were expressed in $\mathrm{pH}$ units. For TTA, $10 \mathrm{ml}$ of the sample was transferred to a $100 \mathrm{ml}$ volumetric flask and filled with $\mathrm{CO}_{2}$-free distilled water. This solution was titrated with a standard solution of $0.1 \mathrm{~mol} \mathrm{~L}^{-1}$ sodium hydroxide (NaOH) (IAL, 2008).

Only berry skin was used for the extraction of total anthocyanins (TA). To do this, the skin of one thousand berries per treatment (3 blocks $\times 3$ replicates $=9$ samples) was manually separated from the pulp. Previously, weighed skin was mixed with an acidic $(1 \% \mathrm{HCl})$ ethanol solution (70:30) (Ju and Howard, 2003) at a ratio of 1:3 (m/v) and crushed in a blender (Arno, Clic Lav Top, Brazil) for $40 \mathrm{~s}$ at slow speed (1500 RPM), and another $40 \mathrm{~s}$ at high speed (3500 RPM). The resulting solution was put in a $250 \mathrm{ml}$ beaker, allowed to stand in the dark for $30 \mathrm{~min}$ at room temperature $\left(20 \pm 1{ }^{\circ} \mathrm{C}\right)$, and then centrifuged at 3500 RPM for five minutes. The supernatant was collected in an amber glass vial and stored under refrigeration (4-10 $\left.{ }^{\circ} \mathrm{C}\right)$. Extraction was carried out in triplicate at the laboratory. TA content was determined by the $\mathrm{pH}$ difference method (Giusti and Wrolstad, 2001), in which samples are dissolved in two buffer systems: $0.025 \mathrm{~mol} \mathrm{~L}^{-1}$ potassium chloride ( $\mathrm{pH}$ 1.0) and $0.4 \mathrm{~mol} \mathrm{~L}^{-1}$ sodium acetate ( $\mathrm{pH} 4.5$ ). Absorbance was measured at $515 \mathrm{~nm}$ and at $700 \mathrm{~nm}$ using UV-vis spectrophotometer (FEMTO 600 plus, Brazil). Absorbance was calculated using Eq. 1:

$A=(\text { A515 vis }- \text { A700nm })_{\text {pH1.o }}-(\text { A515 vis }- \text { A700nm })_{p H 4.5}$

Pigment concentration in the extract was calculated and represented in cyanidin-3-glucoside ( $\mathrm{MW}=449.2$ and $\varepsilon=26,900)$ (Eq. 2).

Anthocyanins $\left(m g L^{-1}\right)=(A \times M W \times D F \times 1000) /(\varepsilon \times 1)$

where: $\mathrm{A}=$ absorbance; $\mathrm{MW}=$ molecular weight; $\mathrm{DF}=$ dilution factor, and $\varepsilon=$ molar absorptivity.

\subsection{Statistical analysis}

For all the response variables considered in this study, we fitted a linear mixed model considering modes of $\mathrm{N}$ supply and years as the interaction between these factors (fixed effect) and the effects of blocks nested in years (random effect). The normality of residuals was tested through the Shapiro-Wilk test to check if any transformation would be needed. Additionally, the model was fitted with homogenous and heterogeneous variances for different years. Model selection for the correlation structure was done following the Akaike information criteria (AIC), Bayesian information criterion (BIC), and Likelihood Ratio Test (LRT). All the models were fitted using the R (R core team, 2017) "nlme" package (Pinheiro et al., 2016). Whenever the null hypothesis (equal means) was rejected with alpha equal to 0.05 , the means were compared by the Scott-Knott test.

A regression analysis was performed between yield per plant and leaf $\mathrm{N}$ concentration at flowering and at veraison. Linear models of first and second degree and exponential models were explored in order to find the best mathematical model to describe these relationships. The models were compared by the Akaike Information Criterion (AIC) and Bayesian Information Criterion (BIC). The lowest values represented the best fits.

Additionally, principal component analysis (PCA) was performed combining all the response variables that were evaluated during the four years of the experiment using the $\mathrm{R}$ factoextra and FactoMineR packages. PCA is generally used to find the weights of each variable in order to maximize the variance among sampling points (Ortega et al., 1999). Thus, PCA finds a set of standardized linear combinations called the principal components (PC), which are orthogonal and together explain all the variance of the original data. This kind of analysis allows us identify more complex interactions between the evaluated variables and identify those with greater contribution to the differences among our treatments. In our analysis, we just kept the PC with eigenvalues higher than 1 .

As a last step, a mixed model was fitted for the variables related to $\mathrm{N}$ loss, and nitrate and ammonium leaching. Considering that ammonium and nitrate leaching were analyzed in only one of the four years (2014), the factor year was removed from the mixed model. Since the samples were taken at different times, we assume our residual error potentially correlated under two covariance models: an autocorrelation structure of order 1 and autocorrelation structure of order 1 with a continuous time covariate. The same aforementioned statistical criteria were used for 

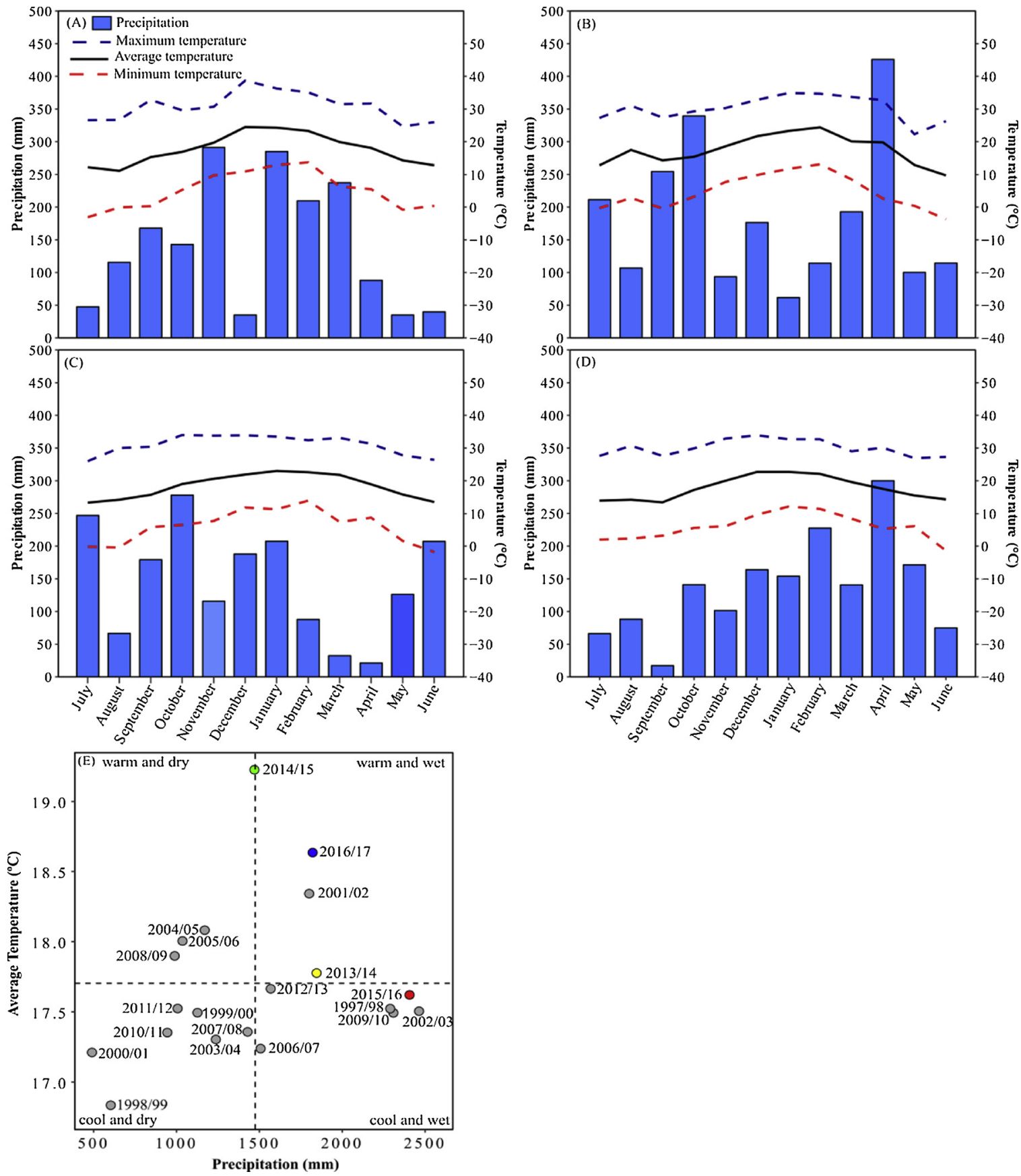

Fig. 1. Minimum, average, maximum temperatures $\left({ }^{\circ} \mathrm{C}\right)$ and monthly accumulated precipitation (mm) during 2013/14 crop season (A), 2014/15 (B), $2015 / 16$ (C) and 2016/17 (D). Spatial distribution of the average temperature and accumulated precipitation from 1997/98 to 2016/17 obtained at the experimental station in Santana do Livramento, state of Rio Grande do Sul, Brazil. Dashed lines depict the average of the last 20 years for precipitation $(\mathrm{mm})$ and average temperature $\left({ }^{\circ} \mathrm{C}\right)$.

model comparison. Whenever the null hypothesis (equal means) was rejected with alpha equal to 0.05 , a regression analysis was performed by the least square means (adjusted means). For ammonium leaching, three different models (linear, quadratic and quadratic-plus-plateau) were used, while a power model was used for nitrate leaching. The $\mathrm{R}$ "nls" function was used to fit the non-linear models.

\section{Results}

Minimum, average and maximum temperatures as well as monthly accumulated precipitation during 2013/14, 2014/15, 2015/16 e 2016/ 17 seasons are presented in Fig. 1(a-d). Similarly, in Fig. 1e is presented the behavior of these harvests in relation to the climatic normal of the last 20 years. The analysis of variance components was performed for the variable groups of nutrition and growth (leaf $\mathrm{N}$ concentration and stem diameter, both at flowering and veraison), grape yield (yield per plant, number of clusters per plant, number of berries per cluster, weight of 100 berries) and the must (pH, TSS, TTA and TA), considering the treatments (modes of N supply), crop seasons (2013/14, 2014/15, 2015/16, 2016/17), crop season and treatment interaction, and blocks and residuals as sources of variation. We disregarded variation that was not explained by the model (residuals), and the effect of crop season was predominant in explaining data variation for all the variables considered in this study, except for TA content, where the effect of the treatment was responsible for more than $50 \%$ of the variation (Fig. 2). 


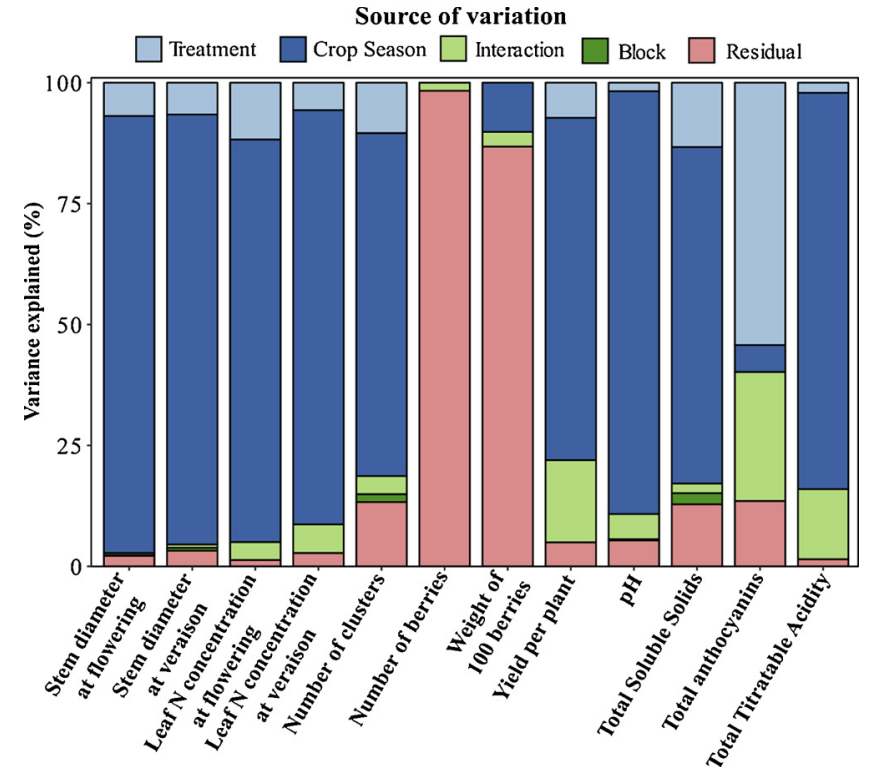

Fig. 2. Colors represent the source of variation (E.G. treatment, years, interactions, block and residual). Response variables are presented in the $\mathrm{X}$ axis. Proportion of variance explained by each source of variation for each response variable is present in Y axis. (NF- Nitrogen fertigation; NFI- Nitrogen application followed by irrigation; NWI- Nitrogen application without irrigation; $1 / 2 \mathrm{NF}$ $1 / 2$ Nitrogen fertigation; C- Control without nitrogen).

\subsection{Leaf $N$ concentration and stem diameter}

Grapevines subjected to fertigation (NF) showed higher leaf N concentration at flowering in the four crop seasons (Fig. 3A). $\mathrm{N}$ application followed by irrigation (NFI) increased leaf $\mathrm{N}$ concentration at flowering in 2014/15, 2015/16 and 2016/17 (Fig. 3A). At veraison, grapevines subjected to NF in 2013/14, 2014/15 and 2015/16 showed the greatest increase in leaf $\mathrm{N}$ concentration, followed by those subjected to NFI in 2014/15 and 2016/17 (Fig. 3B).

Grapevines subjected to NFI exhibited the highest values of stem diameter at flowering and veraison in all the crop seasons (Fig. 3C).
Grapevines subjected to NF also showed stems with larger diameter at flowering and veraison, however, only in 2014/15, 2015/16 and 2016/ 17 (Fig. 3D).

\subsection{Grape yield}

Grapevines grown in soil subjected to NF, NFI and $1 / 2$ NF showed higher grape yield in 2013/14 compared to NWI and C (Fig. 4D). In $2014 / 15$ and $2016 / 17$, the highest grape yields were those of grapevines grown in soil with NF and NFI. In 2015/16, grapevines grown in soil with $1 / 2 \mathrm{NF}$ had the highest grape yield. It should be noted that grape yield varied between treatments and crop seasons, and that the lowest grape yield observed was $0.38 \mathrm{~kg}$ plant $^{-1}$ and the highest was $15 \mathrm{~kg}$ plant $^{-1}$. Grapevines subjected to NF showed the highest number of clusters per plant in all the crop seasons, followed by those grown in soil with NFI in 2013/14, 2014/15 and 2016/17 (Fig. 4A). Grapevines with NF and NWI presented the highest numbers of berries per cluster in the 2015/16 crop season (Fig. 4C). The weight of 100 berries did not differ statistically among treatments in all the crop seasons (Fig. 4B).

\subsection{Chemical parameters of the must}

The highest values of total titratable acidity (TTA) were found in the must of the grapevines subjected to NFI in the 2013/14 and 2014/15 crop seasons (Fig. 5A). However, the highest values of TTA in 2015/16 and 2016/17 were found in the must of grapevines grown in NF. The must of grapevines grown in $\mathrm{C}$ showed the highest concentrations of total anthocyanins (TA) in all the crop seasons (Fig. 5B). The must of grapevines subjected to NFI and NF showed the lowest TA concentrations in 2013/14, 2014/15, 2015/16 and 2016/17, respectively. The highest values of $\mathrm{pH}$ in the must (Fig. $5 \mathrm{C}$ ) were found in grapevines subjected to C in 2013/14, 2014/15 and NFI in 2015/16 and 2016/17. Grapevines grown in control soil without $\mathrm{N}$ fertilization had the highest values of total soluble solids (TSS) in the must in all the crop seasons (Fig. 5D). However, the must of grapevines subjected to NWI in 2014/ 15 and 2015/16 also showed high values of TSS (Fig. 5D).
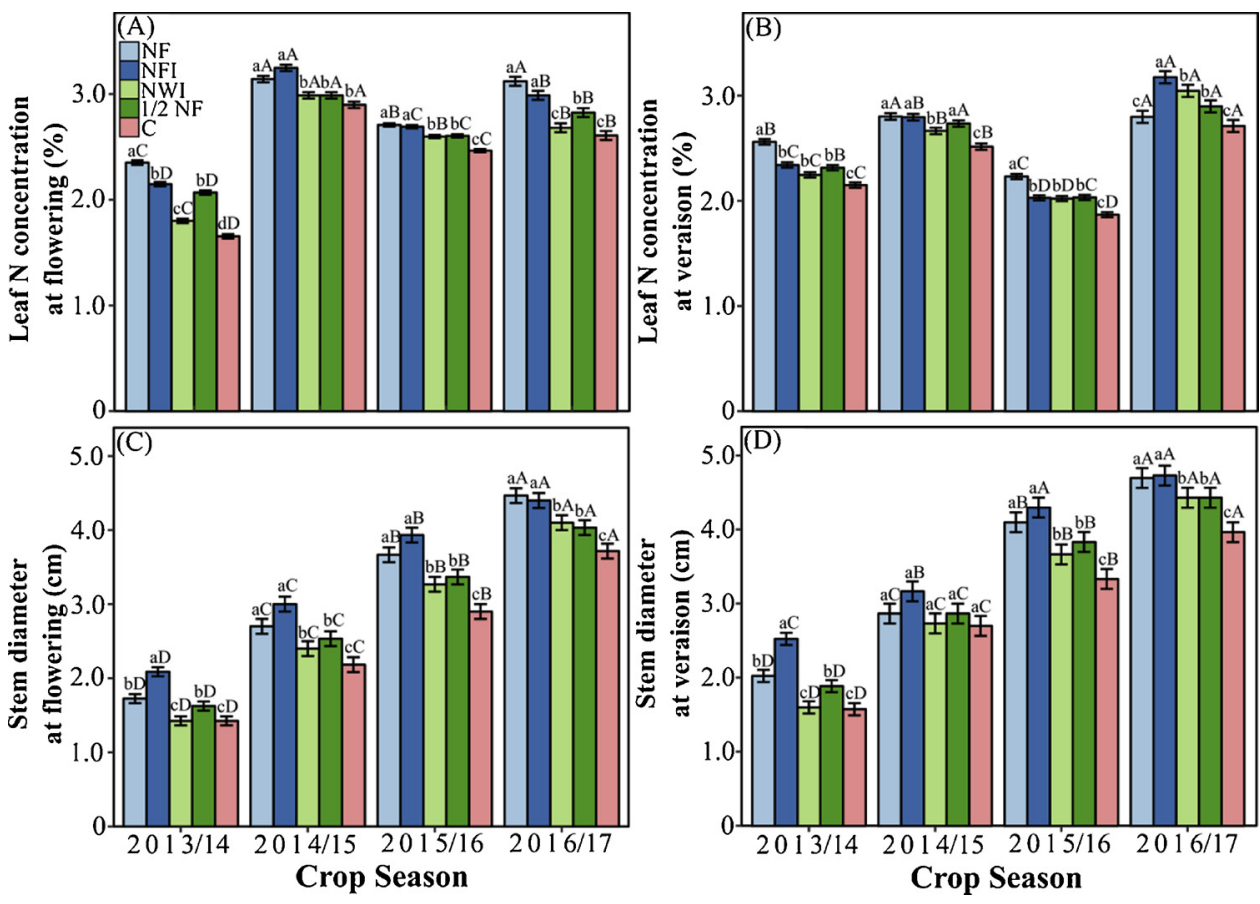

Fig. 3. Leaf $\mathrm{N}$ concentration at flowering (A) and veraison (B); stem diameter at flowering (C); and veraison (D) of 'Alicante Bouschet' grapevines subjected to different methods of $\mathrm{N}$ supply (NF- Nitrogen fertigation; NFI- Nitrogen application followed by irrigation; NWINitrogen application without irrigation; $1 / 2 \mathrm{NF}$ $1 / 2$ Nitrogen fertigation; C- Control without nitrogen). Different lower-case letters indicate a significant difference among different $\mathrm{N}$ supply methods in the same year, and different uppercase letters indicate a significant difference among the crop seasons for each $\mathrm{N}$ supply method by the Skott-Knott test $(\mathrm{P}<0.05)$. 

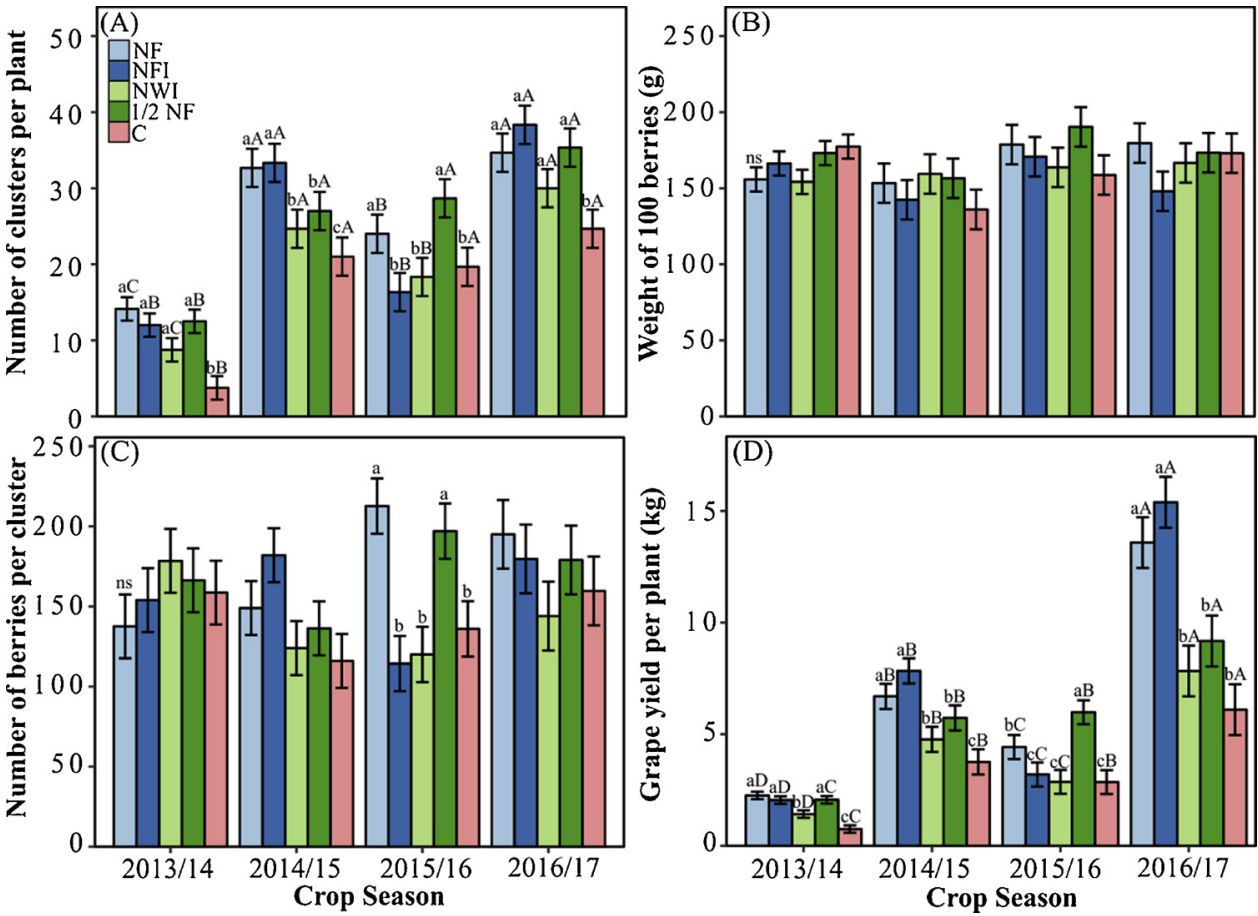

Fig. 4. Yield components of 'Alicante Bouschet' grapevines subjected to different methods of $\mathrm{N}$ supply (NF- Nitrogen fertigation; NFI- Nitrogen application followed by irrigation; NWINitrogen application without irrigation; $1 / 2 \mathrm{NF}$ $1 / 2$ Nitrogen fertigation; C- Control without nitrogen). Number of clusters per plant (A), weight of 100 berries (B), number of berries per cluster (C) and grape yield per plant (D). Different lower-case letters indicate a significant difference among different $\mathrm{N}$ supply methods in the same year, different upper-case letters indicate a significant difference among the crop seasons for each $\mathrm{N}$ supply method, and ns is not significant by the Skott-Knott test $(\mathrm{P}<0.05)$

\subsection{Concentration of $N$ forms in soil solution}

The concentrations of ammonium in solution of the soil subjected to fertigation (NFI and $1 / 2 \mathrm{NF}$ ) were explained with a mathematic fit of the quadratic-plus-plateau model, while the other treatments were explained by the linear first degree model. In general, solutions collected in soil subjected to $\mathrm{NF}$ and $1 / 2 \mathrm{NF}$ showed the highest ammonium concentrations (Fig. 6A). However, ammonium concentrations in solution of the soil subjected to NF and $1 / 2 \mathrm{NF}$ remained constant until 123 days after application date (Fig. 6A). The lowest ammonium concentrations were found in the control soil throughout the evaluation period. The relationship between the concentration of nitrate in soil solution and application date was described by a power function. The concentrations of nitrate in solution showed a rapid decrease in the first days after the application of the treatments and tended to stabilize over time. The highest nitrate concentrations were found in NF and $1 / 2 \mathrm{NF}$ (Fig. $6 \mathrm{~B}$ ). The lowest nitrate concentrations were found in the control soil at all the collection dates (Fig. 6B).

\subsection{Principal component analysis (PCA)}

For principal component analysis (PCA), only the first two components were extracted, because together they explained $65.8 \%$ of the total variability of the data (Fig. 7). Component 1 (PC1) explained $50.8 \%$ of the variability, with greater influence of TTA, yield, leaf N concentration at flowering and number of clusters per plant, which
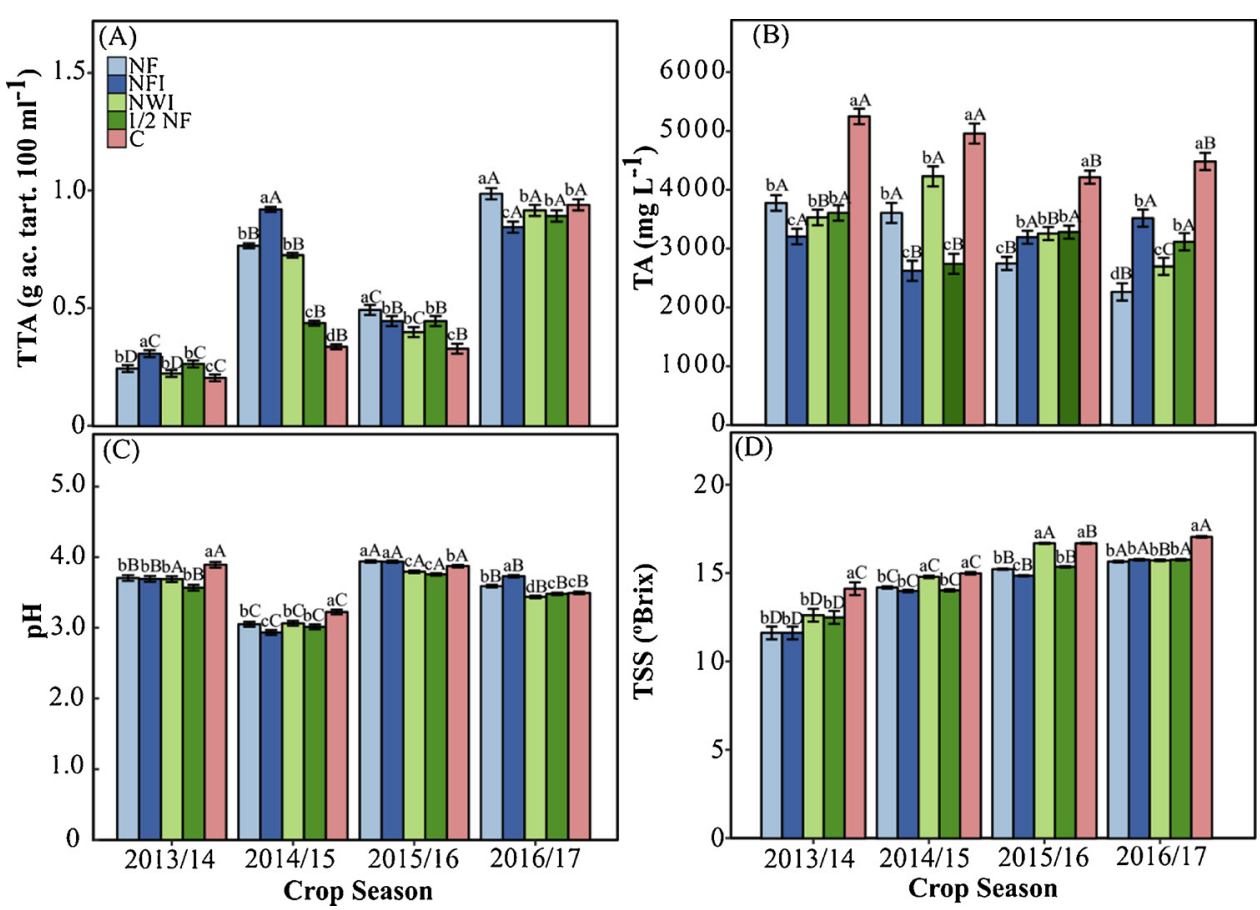

Fig. 5. Chemical parameters of the must of 'Alicante Bouschet' grapevines subjected to different methods of $\mathrm{N}$ supply (NF- Nitrogen fertigation; NFI- Nitrogen application followed by irrigation; NWI- Nitrogen application without irrigation; $1 / 2 \mathrm{NF}-1 / 2$ Nitrogen fertigation; CControl without nitrogen).Total titratable acidity (TTA) (A); total anthocyanins (TA) (B); $\mathrm{pH}$ (C); and total soluble solids (TSS) (D). Different lower-case letters indicate a significant difference among different $\mathrm{N}$ supply methods in the same year, and different uppercase letters indicate a significant difference among the crop seasons for each $\mathrm{N}$ supply method by the Skott-Knott test $(\mathrm{P}<0.05)$. 


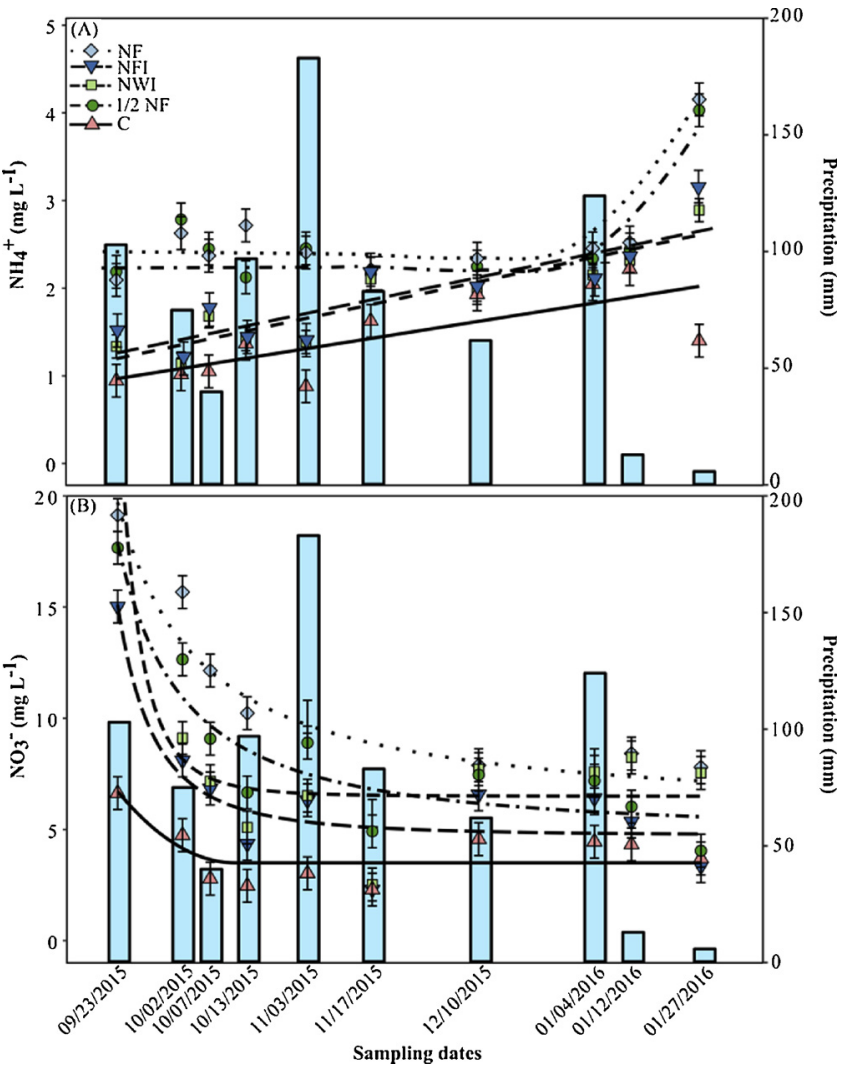

Fig. 6. Concentrations of ammonium $\left(\mathrm{NH}_{4}{ }^{+}\right)$(A) and nitrate $\left(\mathrm{NO}_{3}{ }^{-}\right)$(B) in solution of the soils grown with 'Alicante Bouschet' grapevines subjected to different methods of $\mathrm{N}$ supply during 10 precipitation events (NF- Nitrogen fertigation; NFI- Nitrogen application followed by irrigation; NWI- Nitrogen application without irrigation; $1 / 2 \mathrm{NF}$ - $1 / 2$ Nitrogen fertigation; C- Control without nitrogen). Vertical bars indicate the standard error $(p<0.001) .\left(\mathrm{NH}_{4}{ }^{+}=(\mathrm{NF})\right.$ $\mathrm{y}=60.705986-0.946492 * \mathrm{x}+0.003838 * \mathrm{x}^{2}$ plateau at 123.3 DAA; $(1 / 2 \mathrm{NF})$ $\mathrm{y}=12.3717648-0.1984223 * \mathrm{x}+0.0009721 * \mathrm{x}^{2}$ plateau at $102.1 \mathrm{DAA}$; (NFI) $y=10.3868+0.01132 * x ; \quad$ (NWI) $y=0.9248+0.0111^{*} x ; \quad$ (C) $\left.\mathrm{y}=0.9248+0.0111^{*} \mathrm{x}\right) ;\left(\mathrm{NO}_{3}{ }^{-}=(\mathrm{NF}) \mathrm{y}=5.571+332.559 * \mathrm{x}^{-1.072} ;(1 / 2 \mathrm{NF})\right.$ $\mathrm{y}=4.733+723.163 * \mathrm{x}^{-1.361} ; \quad$ (NFI) $\quad \mathrm{y}=6.480+6,575,000 * \mathrm{x}^{4.342} ; \quad$ (NWI) $\mathrm{y}=4.711+14,640.121 * \mathrm{x}^{-2.463} ;(\mathrm{C}) \mathrm{y}=13.270419-0.439530 * \mathrm{x}+0.004933$ $* \mathrm{x}^{2}$ plateau at 44.5 days after application).

were positively correlated with one another, and TA concentration in the must, which presented a negative correlation with the aforementioned variables. Principal component 2 (PC2) explained 15\% of the variability and was primarily influenced by the weight of 100 berries, number of berries per cluster and $\mathrm{pH}$ values in the must. There was a clear distinction among the crop seasons in PCA, which was in line with the analysis of the variation components, demonstrating that this factor explained a large part of the original variability of the data (Fig. 2).

\section{Discussion}

The analysis of variance showed that the treatments presented a behavioral tendency for all the crop seasons, varying only in the amplitude of the values. This caused the variable crop season to be the most influential in the total variation of the data. However, the crop seasons were different from one another when considering climatic variables such as temperature and accumulated precipitation during the cycle of the grapevine (Fig. 1A-E).

In most crop seasons, the highest leaf $\mathrm{N}$ concentrations at flowering were found in grapevines subjected to the application of $\mathrm{N}$ via NF or NFI (Fig. 3A). This most likely happened because irrigation and fertigation water promoted the dissolution of urea, accelerating hydrolysis by urease. This resulted in the formation of ammonium carbonate,

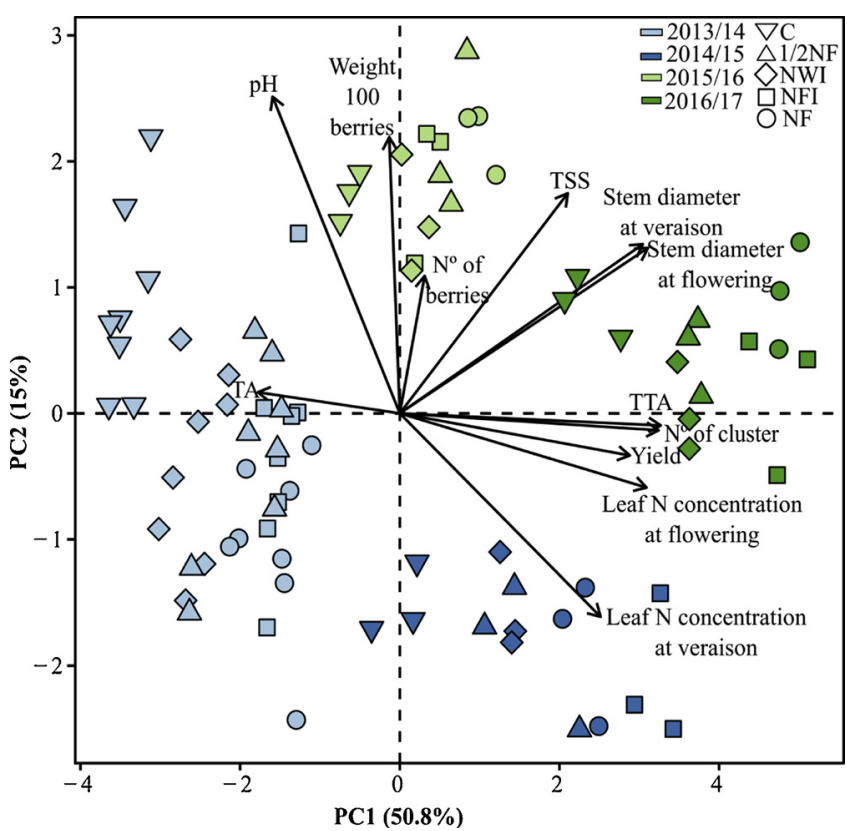

Fig. 7. Relationship between principal component 1 (PC1) and principal component 2 (PC2) for variable groups of growth (leaf $\mathrm{N}$ concentration at flowering and veraison, stem diameter at flowering and veraison), yield (total number of clusters per plant, yield per plant, weight of 100 berries and number of berries per cluster) and chemical parameters of the must (TSS, pH, TTA and TA) in 'Alicante Bouschet' grapevines subjected to different methods of N supply (NFNitrogen fertigation; NFI- Nitrogen application followed by irrigation; NWINitrogen application without irrigation; $1 / 2 \mathrm{NF}-1 / 2$ Nitrogen fertigation; CControl without nitrogen).

which rapidly decomposes, resulting in hydroxyl, carbonate and ammonium, and which may subsequently be converted to nitrite $\left(\mathrm{NO}_{2}{ }^{-}\right)$ and nitrate $\left(\mathrm{NO}_{3}{ }^{-}\right)$through biological oxidation (Brunetto et al., 2016). Furthermore, after the application of urea, the water used in fertigation and irrigation may have promoted the migration of mineral $\mathrm{N}$ forms, especially nitrate, in the soil profile to regions with a higher concentration of roots (Barlow et al., 2009); and may also have been moved by mass flow of the mineral $\mathrm{N}$ forms from the soil solution to the outer root surface (Bravo et al., 2012).

Grapevine roots can absorb water as well as $\mathrm{N}$ forms, including those derived from fertilizer applied via NF or NFI. It should also be noted that higher concentrations of nitrate in soil and in solution tend to stimulate the emission of fine roots in fruit tree species. These roots are responsible for water and nutrient uptake, but with maintenance energy expenditure of nearly $90 \%$ (Ceccon et al., 2016). Part of the $\mathrm{N}$ absorbed by the roots may have been accumulated in the form of amino acids (glutamate, glutamine, aspartate, and asparagine) (Marschner, 2012). The rest of the $\mathrm{N}$ may have been transported via xylem to shoot organs (leaves), which during the vegetative and productive growth of the grapevine show intense cell division and elongation, increasing green matter and dry matter (Zapata et al., 2004). Therefore, the leaves became sinks for nutrients, including N (Brunetto et al., 2014; Schreiner and Scagel, 2006).

In most crop seasons, leaves collected at veraison also showed greater increase in $\mathrm{N}$ concentration in grapevines subjected to NF and NFI (Fig. 3B). However, leaf $\mathrm{N}$ concentrations at veraison were smaller than those at flowering. This is a result of the larger leaf area, which promoted the dilution of $\mathrm{N}$ concentration in the leaves (Agnelli et al., 2014). Moreover, part of the nitrogen compounds in the leaves (e.g., proteins and amino acids) during veraison may have been degraded and $\mathrm{N}$ redistributed to other growing annual organs, such as the clusters or branches of the year (Brunetto et al., 2009; Metay et al., 2015) or to perennial reserve organs, such as branches of the year, stem and 


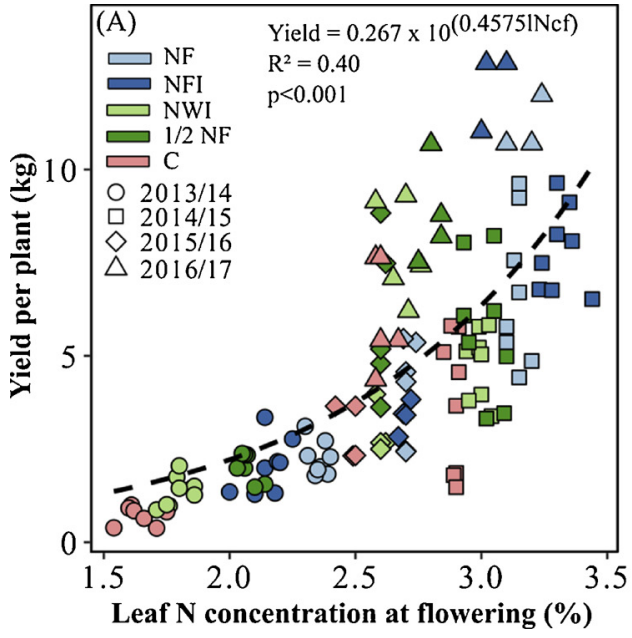

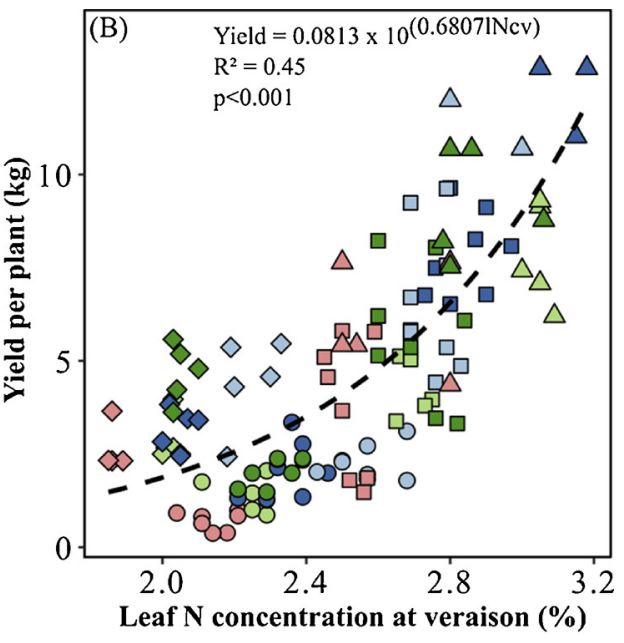

Fig. 8. Correlation between yield per plant $(\mathrm{kg})$ and leaf $\mathrm{N}$ concentration at flowering (A) and veraison (B) in 'Alicante Bouschet' grapevines subjected to different methods of $\mathrm{N}$ supply (NF- Nitrogen fertigation; NFI- Nitrogen application followed by irrigation; NWINitrogen application without irrigation; $1 / 2 \mathrm{NF}$ $1 / 2$ Nitrogen fertigation; C- Control without nitrogen; INcf- Leaf Nitrogen concentration at flowering; $1 \mathrm{Ncv}$ - Leaf Nitrogen concentration at veraison). especially roots (Brunetto et al., 2014).

The analysis of correlation between leaf $\mathrm{N}$ concentration at flowering and veraison with yield per plant (Fig. 8A, B) showed positive exponential behavior. Thus, there was a higher correlation between the factors during veraison $\left(\mathrm{R}^{2}=0.45, \mathrm{p}<0.001\right)$ compared to correlation at flowering $\left(\mathrm{R}^{2}=0.40, \mathrm{p}<0.001\right)$. The higher correlation of yield and $\mathrm{N}$ concentration at veraison may be due to the fact that this phenological stage is closer to physiological maturation, and $\mathrm{N}$ redistribution is possibly already underway. However, the advancement of the crop cycle hinders a possible intervention for nitrogen fertilizer management, and may also indirectly impact the composition of the grape, if the grapevine fails to produce enough anthocyanin compounds for the berries (Tarara et al., 2008). It was also possible to verify the distribution of the treatments with correlation, where NF and NFI showed the highest leaf $\mathrm{N}$ concentrations and, consequently, the greatest increases in yield (Fig. 8A, B).

At flowering and veraison, the highest values of stem diameter of grapevines subjected to N application, especially NFI and NF (Fig. 3C, D), occurred because of the higher uptake of $\mathrm{N}$ derived from the fertilizer (Lorensini et al., 2017). This assumption is adequate and based on the increase in leaf $\mathrm{N}$ concentration found at flowering and veraison (Fig. 3A, C), which reinforces the hypothesis that part of the $\mathrm{N}$ applied to the soil was absorbed by the grapevines during the same cycle. The growth of the grapevine, that is, the increased number of cells with the duplication of cellular material, which can be measured by the stem diameter, requires carbon (C) and N. This demand occurs simultaneously when the plant performs photosynthesis to produce glucose, cellulose and proteins (Marschner, 2012). Also, when the supply of $\mathrm{N}$ in the soil is sufficient, or even when nitrogen fertilizer is applied, the sources of matter and energy are available in the system and the plant may have an increase in photosynthesis (Kizildeniz et al., 2015). Part of the $\mathrm{N}$ absorbed by the roots is in the form of nitrate and this uptake occurs by means of symporters, with energy expenditure. Nitrate must be reduced to nitrite by nitrate reductase, subsequently reduced to ammonium by nitrite reductase for it to finally be assimilated. $\mathrm{N}$ concentration in the plant will be responsible for directing C flow to produce proteins or carbohydrates. Thus, grapevines subjected to NF and NFI, which had higher leaf $\mathrm{N}$ concentrations, probably also required more energy for protein synthesis (Ceccon et al., 2016). On the other hand, grapevines subjected to NWI and C, whose leaves had lower concentrations of $\mathrm{N}$, were dedicated to the production of carbohydrates instead of proteins, demonstrating the correlation between $\mathrm{N}$ concentration and increased plant biomass (Lawlor, 2002).

Yield and number of clusters per plant varied throughout the crop seasons in all the treatments. This most likely occurred because the grapevines were young and naturally grew over the years. This behavior was diagnosed by increased stem diameter and visual plant growth (Fig. 3C, D). The increase of the plant canopy and the productive capacity of the grapevine throughout the crop seasons are natural physiological processes and accelerated by $\mathrm{N}$ application to the soil. The high yield in a given crop can reduce floral induction after bud break, initial inflorescence growth and floral differentiation and, consequently, decrease yield in a succeeding crop (Guilpart et al., 2014). However, in all the crop seasons, grapevines subjected to $\mathrm{N}$ application via NFI, NF and $1 / 2 \mathrm{NF}$ showed higher yields and number of clusters per plant compared those subjected to NWI and C (Fig. 4A, D). Grapevines grown in soil without fertilization (C) had lower yields along the crop seasons most likely because the amount of mineralized $\mathrm{N}$ of organic matter, senescent residues (roots and shoots) of cover crop species and grapevines (pruned leaves and branches) were insufficient to meet annual demand of the plants (Muscas et al., 2017). Grapevines subjected to NWI most likely had lower yield because part of the fertilizer $\mathrm{N}$ applied to the soil surface may have been lost by volatilization in the form of $\mathrm{NH}_{3}{ }^{-}-\mathrm{N}$ (Lorensini et al., 2012). On the other hand, NFI, NF and $1 / 2 \mathrm{NF}$ increased the concentration of mineral $\mathrm{N}$ forms in soil and solution (Fig. 6A, B), potentiating the uptake of $\mathrm{N}$ forms by the grapevines. It should be noted that grapevines subjected to fertigation of half the recommended $\mathrm{N}$ dose $(1 / 2 \mathrm{NF})$ for the sandy soil under study, $20 \mathrm{~kg} \mathrm{~N}$ ha

${ }^{1}$ was enough to promote yields similar to those found in grapevines subjected to the recommended N dose applied via NF and NFI in 2013/ 14 and $2015 / 2016$. This possibly happened because the $\mathrm{N}$ derived from the fertilizer applied via fertigation was lost in smaller amounts by volatilization, leaching and denitrification, which increases $\mathrm{N}$ uptake by the grapevines (Brunetto et al., 2016). This result corroborates the findings of Brunetto et al. (2009), who reported that the maximum yield in grapevines grown in sandy soils with low organic matter content was reached with doses close to $20 \mathrm{~kg} \mathrm{~N} \mathrm{ha}^{-1}$.

The values of TTA in the must varied in the same way as yield during the crop seasons in all the treatments (Fig. 5A). In the crop seasons where the highest values of TTA in the must were found, the lowest $\mathrm{pH}$ values were verified (Fig. 5C). Stoichiometrically, there is no relationship between the $\mathrm{pH}$ of the must and TTA, since acidity is based on the concentration and the type of acid in the medium, and tartaric, malic and citric acids are typically present in grape's must. Tartaric acid is present in large quantities in grapevines, and because it is a strong acid, it is resistant to oxidative respiration, favoring the persistence of acidity in wine, in addition to directly interfering in the $\mathrm{pH}$ (Brunetto et al., 2009). On the other hand, malic acid in the berry is a product of the oxidation of glucose in respiration (Ribéreau-Gayon, 1968). Moreover, $\mathrm{pH}$ is only dependent on the ionization capacity, and if tartaric acid predominates over malic acid in the must, $\mathrm{pH}$ will be lower, and vice versa. The highest values of TTA were found in grape's must 
obtained from plants subjected to NFI and NF (Fig. 5A). This probably happened because the grapevines absorbed larger amounts of mineral $\mathrm{N}$ forms from the soil, which normally stimulate shoot growth, observed by increased stem diameter (Fig. 3C, D) and leaf $\mathrm{N}$ concentration (Fig. 3A, B), resulting in the lower incidence of solar rays inside the grapevines. The greater shading of the grape clusters inside the grapevine hinders canopy aeration to regulate temperature, which can promote the incidence of fungal diseases, reducing sugar concentration and increasing acidity in berries and the must (Smart and Robinson, 1991). Temperature variation also influences the composition of the grape, due to the photochemical degradation of the acids. Thus, grapes harvested in crop seasons with higher temperatures (2014/15) will probably have lower TTA compared to those harvested in crop seasons with lower temperatures (2013/14) (Sadras and Moran, 2012).

The highest values of TSS in the must, which usually consist of $95 \%$ sugars (Smart and Robinson, 1991), were found in C in all the crop seasons and also in NWI in 2014/15 and 2015/16 (Fig. 5D). This was due to the lower number of clusters per plant, which were noticeably smaller in length and width, resulting in lower yield (Fig. 4A, D). Thus, TSS tends to concentrate more in the berries of smaller clusters (Guilpart et al., 2014). On the other hand, grapevines in NFI and NF achieved the highest yields (Fig. 4D), and this may have stimulated the dilution of photoassimilates, such as sugars in the formation of the berries (Antolín et al., 2003).

The highest values of TA were found in grape must of grapevines grown in control soil without $\mathrm{N}$ fertilization (C) (Fig. 5B). This is mainly due to the higher pulp/skin ratio with low yields (Fig. 4D), which increases the TA concentration per area unit in berries and, consequently, in the must (Castellarin et al., 2007). Moreover, grapevines without $\mathrm{N}$ application had lower shoot growth, verified in stem diameter (Fig. 3C, D), since which there might be a bigger competition for carbohydrates allocated to fruits and shoots/leaves (Cheng et al., 2014). In addition, a higher incidence of solar rays on the berries is expected in grapevines with lower shoot vigor, and this may increase the activity of enzymes responsible for the production of TA. On the other hand, the must of grapevines subjected to $1 / 2 \mathrm{NF}, \mathrm{NF}, \mathrm{NFI}$ and NWI showed lower values of TA. This was especially the case because of the dilution of TA in berries due to the lower pulp/skin ratio, and, consequently, in the must, as the highest yields were observed in these grapevines (Kizildeniz et al., 2015); and by the redistribution of TA from berries to growing annual organs (Cheng et al., 2014). The decrease in TA concentration may be undesirable, especially in 'Alicante Bouschet', since its grape is often used in wines made from the mixing of different grape cultivars, because of its intense red coloring (Webb et al., 2006).

The highest concentrations of ammonium and nitrate in soil solution were found in NF and $1 / 2 \mathrm{NF}$ (Fig. $6 \mathrm{~A}, \mathrm{~B}$ ). This is because $\mathrm{N}$ provided by fertigation (in liquid form) rapidly increases soil $\mathrm{N}$ forms (especially nitrate). Treatments where $\mathrm{N}$ was applied in solid form (NFI and NWI) required a longer period for hydrolysis and formation of by-products. The concentrations of nitrate in solution decreased with the advancement of the collections, more markedly in NF and $1 / 2 \mathrm{NF}$, but also in NFI and NWI. This was probably due to the fact that part of the $\mathrm{N}$ forms were absorbed by the roots of the grapevines, which are emitted in large numbers in phenological stages such as flowering (Schreiner and Scagel, 2006), and coincided with the first four collections of soil solution. Moreover, grapevines also have intense cell division and elongation in annual shoot organs in this phenological stage. This can increase transpiration and, consequently, favor the approaching of mineral $\mathrm{N}$ forms to the outer root surface, by pressure gradient and concentration, and also by the internal flow of $\mathrm{N}$ (Taiz and Zeiger, 2013). The decrease in the concentration of nitrate in solution can also be partly attributed to its movement in the sandy soil profile to layers lower than those with lower root concentration (Ceccon et al., 2016), which may potentiate subsurface water contamination if the water flow occurs over a long period of time (Castellanos et al., 2013).

PCA clearly separated the crop seasons into four groups. Within these separations, one can observe the unique behavior of the control treatment, always positioned to the left of the others, as well as the grouping of NFI and NF, always to the right of the other treatments (Fig. 7). The main negative correlation found was between TA and yield. Thus, as yield increased, there was less intense red coloring in the must, which especially corroborates the hypothesis of the dilution of TA in the berries (Cheng et al., 2014) and for the possible competition enter growing organs, in this case, berries with leaves or branches of the year for carbohydrates (Tarara et al., 2008).

\section{Conclusions}

Nitrogen application followed by irrigation or $\mathrm{N}$ supplied via fertigation in most crop seasons provided a greater increase of nitrate in the soil solution, and this allowed a greater recovery of $\mathrm{N}$ by the plant, observed by the differences in growth of young vines, and in the $\mathrm{N}$ concentration in the leaves in both periods evaluated.

Grapevines submitted to nitrogen fertilization via fertigation or followed by irrigation had yields around two to three times higher than vines subjected to conventional $\mathrm{N}$ supply and control, showing the positive effect of these management practices in vineyards implanted on sandy soils tropical regions.

The N supply methods had little effect on the composition of the must, such as the absolute values to the total soluble solids. However, the concentration of anthocyanins decreased from nitrogen application, regardless of the supply method, and the highest values were observed in the control. Which possibly happened due to the increase in yield, and alteration of the pulp/skin ratio.

\section{Acknowledgements}

We thank all staff and students responsible for the maintenance and data collection from this field trial. This study was financed in part by the Coordenação de Aperfeiçoamento de Pessoal de Nível Superior Brasil (CAPES) - Finance Code 001.

\section{References}

Agnelli, A., Bol, R., Trumbore, S.E., Dixon, L., Cocco, S., Corti, G., 2014. Carbon and nitrogen in soil and vine roots in harrowed and grass-covered vineyards. Agric. Ecosyst. Environ. 193, 70-82.

Antolín, M.C., Baigorri, H., De Luis, I., Aguirrezabal, F., Geny, L., Broquedis, M., SánchezDíaz, M., 2003. ABA during reproductive development in non-irrigated grapevines (Vitis vinifera L. cv. Tempranillo). Aust. J. Grape Wine Res. 9, 169-176.

AOAC. Association of Official Analytical Chemists, 2005. Official Methods of Analysis of AOAC International, $18^{\text {th }}$ ed. AOAC International, Maryland $1750 \mathrm{p}$.

Arrobas, M., Ferreira, I.Q., Freitas, S., Verdial, J., Rodrigues, A., 2014. Guidelines for fertilizer use in vineyards based on nutrient content of grapevine parts. Sci. Hortic. 172, 191-198.

Barlow, K., Bond, W., Holzapfel, B., Smith, J., Hutton, R., 2009. Nitrogen concentrations in soil solution and surface run-off on irrigated vineyards in Australia. Aust. J. Grape Wine Res. 15, 31-143.

Bravo, K., Toselli, M., Baldi, E., Marcolini, G., Sorrenti, G., Quartieri, M., Marangoni, B., 2012. Effect of organic fertilization on carbon assimilation and partitioning in bearing nectarine trees. Sci. Hortic. 137, 100-106.

Brunetto, G., Ceretta, C.A., Kaminski, J., Melo, G.W.B., Girotto, E., Trentin, E.E., Lourenzi, C.R., Vieira, R.C.B., Gatiboni, L.C., 2009. Produção e composição química da uva de videiras Cabernet Sauvignon submetidas à adubação nitrogenada. Ciência Rural 39, 2035-2041.

Brunetto, G., Ceretta, C.A., Melo, G.W.B., Kaminski, J., Trentin, G., Girotto, E., Ferreira, P.A.A., Miotto, A., Trivelin, P.C.O., 2014. Contribution of nitrogen from agricultural residues of rye to 'Niagara Rosada' grape nutrition. Sci. Hortic. 169, 66-70.

Brunetto, G., Ceretta, C.A., Melo, G.W.B., Girotto, E., Ferreira, P.A.A., Lourenzi, C.R., Couto, R.R., Tassinari, A., Knevitz, R.H., Stefanello, L.O.S., Lazzaretti, B.P., Kulmann, M.S.S., Carranca, C., 2016. Contribution of nitrogen from urea applied at different rates and times on grapevine nutrition. Sci. Hortic. 207, 1-6.

Castellanos, M.T., Cartagena, M.C., Ribas, F., Cabello, M.J., Arce, A., Tarquis, A.M., 2013. Impact of nitrogen uptake on field water balance in fertirrigated melon. Agric. Water Manage. 120, 56-63.

Castellarin, S.D., Pfeiffer, A., Sivilotti, P., Degan, M., Peterlunger, E., Di Gaspero, G., 2007. Transcriptional regulation of anthocyanins biosynthesis in ripening fruits of grapevine under seasonal water deficit. Plant Cell Environ. 30, 1381-1399.

Ceccon, C., Tagliavini, M., Schmitt, A.O., Eissenstat, D.M., 2016. Untangling the effects of root age and tissue nitrogen on root respiration in Populus tremuloides at different 
nitrogen supply. Tree Physiol. 36, 618-627. https://doi.org/10.1093/treephys/ tpw022.

Cheng, G., He, N., Yue, X., Wang, J., Zhang, W., 2014. Effects of climatic conditions and soil properties on cabernet sauvignon berry growth and anthocyanin profiles. Molecules 19, 13683-13703.

CQFS-RS/SC. Comissão de Química e fertilidade do solo - RS/SC, 2004. Manual de calagem e adubação para os estados do Rio Grande do Sul e de Santa Catarina. SBSCNúcleo Regional Sul/UFRGS, Porto Alegre.

De Conti, L., Ceretta, C.A., Melo, G.W.B., Tiecher, T.L., Silva, L.O.S., Garlet, L.P., Mimmo, T., Cesco, S., Brunetto, G., 2019. Intercropping of young grapevines with native grasses for phytoremediation of Cu-contaminated soils. Chemosphere 216, 147-156.

Embrapa, Empresa brasileira de pesquisa agropecuária, 1997. Manual de métodos de análise de solo. Rio de Janeiro. 212p. .

Fang, Y.L., Sun, W., Wan, L., 2013. Effects of regulated deficit irrigation (RDI) on wine grape growth and fruit quality. Sci. Agric. Sinica 46 (13), 2730-2738.

Flores, S.S., Medeiros, R.M.V., 2013. Ruralities in the comprehension of the wine territories and their identity. Campo-Território: Revista de Geografia Agrária 8, 1-19.

Giusti, M.M., Wrolstad, R.E., 2001. Characterization and measurement of anthocyanins by UV-visible spectroscopy. In: WROLSTAD, R.E. (Ed.), Current Protocols in Food Analytical Chemistry. John Wiley, Sons, New York.

Guilpart, N., Metay, A., Gary, C., 2014. Grapevine bud fertility and number of berries per bunch are determined by water and nitrogen stress around flowering in the previous year. Eur. J. Agron. 54, 9-20.

IAL. Instituto Adolfo Lutz, 2008. Métodos físico-químicos para análise de alimentos. 1. ed. digital. IAL, São Paulo 1020 p.

Ju, Z.Y., Howard, L.R., 2003. Effects of solvent and temperature on pressurized liquid extraction of anthocyanins and total phenolics from dried red grape peel. J. Agric. Food Chem. 51 (18), 5207-5213.

Kelly, M., Giese, W.G., Velasco-Cruz, C., Lawson, L., Ma, S., Zoecklein, B., 2017. Effect of foliar nitrogen and sulfur on petit manseng (Vitis vinifera L.) grape composition. J. Wine Res. 0, 1-16.

Kizildeniz, T., Mekni, I., Santesteban, H., Pascual, I., Morales, F., Irigoyen, J.J., 2015. Effects of climate change including elevated $\mathrm{CO}_{2}$ concentration, temperature and water deficit on growth, water status, and yield quality of grapevine (Vitis vinifera L.) cultivars. Agric. Water Manage. 159, 155-164.

Lawlor, D.W., 2002. Carbon and nitrogen assimilation in relation to yield: mechanisms are the key to understanding production systems. J. Exp. Botany. 53 (370), 773-787.

Lorensini, F., Ceretta, C.A., Girotto, E., Cerini, J.B., Lourenzi, C.R., De Conti, L., Trindade, M.M., Melo, G.W.B., Brunetto, G., 2012. Lixiviação e volatilização de nitrogênio em um Argissolo cultivado com videira submetida à adubação nitrogenada. Ciência Rural. 42, 1173-1179.

Lorensini, F., Ceretta, C.A., De Conti, L., Ferreira, P.A.A., Dantas, M.K.L., Brunetto, G., 2017. Adubação nitrogenada na fase de crescimento de videiras "Chardonnay" e "Pinot Noir" e formas de nitrogênio em solo arenoso do Bioma Pampa. Rev. Ceres. 64, 433-440.

Marschner, P., 2012. Marschner's Mineral Nutrition of Higher Plants. Amsterdam.

Metay, A., Magnier, J., Guilpart, N., Angélique, C., 2015. Nitrogen supply controls vegetative growth, biomass and nitrogen allocation for grapevine (cv. Shiraz) grown in pots. Funct. Plant Biol. 42, 105-114.

Muscas, E., Cocco, A., Mercenaro, L., Cabras, M., Lentini, A., Porqueddu, C., Nieddu, G., 2017. Effects of vineyard floor cover crops on grapevine vigor, yield, and fruit quality, and the development of the vine mealybug under a Mediterranean climate. Agric. Ecosyst. Environ. 237, 203-212.

Ortega, R.A., Wastfall, D.G., Ganfloff, W.J., Peterson, G.A., 1999. Multiveriate approach to $\mathrm{N}$ and $\mathrm{P}$ recommendations in variable rate fertilizer applications. J.V. Stafford (Ed). Proceedings of the Second European Conference on Precision Agriculture 387-396.

Pérez-Álvarez, E.P., Martínez-Vidaurre, J.M., Martín, I., García-Escudero, E., Peregrina, F., 2013. Relationships among soil nitrate nitrogen and nitrogen nutritional status yield components, and must quality in semi-arid vineyards from Rioja AOC, Spain. Commun. Soil Sci. Plant Anal. 44, 232-242.

Pinheiro, J., Bates, D., DebRoy, S., Sarkar, D., R Core Team, 2016. _Nlme: Linear and Nonlinear Mixed Effects Models_. R Package Version 3. URL:. pp. 1-128. http:// CRAN.R-project.org $/$ package $=$ nlme.

Queiroz, A.M.D.E., Souza, C.H.E., Machado, V.J., Lana, R.M.Q., Korndorfer, G.H., Silva, A.A., 2011. Avaliação de diferentes fontes e doses de nitrogênio na adubação da cultura do milho. Revista Brasileira de Milho e Sorgo. 10, 257-266.

R Core Team, 2017. R: A Language and Environment for Statistical Computing. URL. R Foundation for Statistical Computing, Vienna, Austria. https://www.R-project.org/.

Ribéreau-Gayon, G., 1968. Étude des mecanismes de synthese et de transformation de l'acide malique, de l'acide tartrique et de l'acide citrique chez Vitis vinifera. Phytochemistry Elmsford. 7 (9), 1471-1482.

Sadras, V.O., Moran, M.A., 2012. Elevated temperature decouples anthocyanins and sugars in berries of Shiraz and Cabernet Franc. Aust. J. Grape Wine Res. 18, 115-122.

Schreiner, R.P., Scagel, C.F., 2006. Nutrient uptake and distribution in a mature 'pinot noir' vineyard. Hortscience. 41, 336-345.

Smart, R., Robinson, M., 1991. Sunlight Into Wine: A Handbook for Winegrape Canopy Management. Winetitles., Adelaide.

Soil Survey Staff, 2014. Keys to Soil Taxonomy, 12 ed. USDA-NRCS, Washington, DC, USA.

Steenwerth, K.L., Belina, K.M., 2010. Vineyard weed management practices influence nitrate leaching and nitrous oxide emissions. Agric. Ecosyst. Environ. 138, 127-131.

Taiz, L., Zeiger, E., 2013. Fisiologia Vegetal. Artmed, Porto Alegre 820p.

Tarara, J.M., Lee, J., Spayd, S.E., Scagel, C.F., 2008. Berry temperature and solar radiation alter acylation, proportion, and concentration of anthocyanin in merlot grapes. Am. J. Enol. Viticult. 3, 235-247.

Tedesco, M.J., Gianello, C., Bissani, C.A., Bohnen, H., Volkweiss, S.J., 1995. Análise do solo, planta e outros materiais. UFRGS, Porto Alegre.

Webb, L.B., Whetton, P.H., Barlow, E.W.R.S., 2006. Potential impacts of projected greenhouse gas-induced climate change on Australian viticulture. Wine Indust. J. 21 (4), 16-20.

Zapata, C., Dele, E., Chaillou, S., Magne, C., 2004. Partitioning and mobilization of starch and $\mathrm{N}$ reserves in grapevine (Vitis vinifera L.). J. Plant Physiol. 161, 1031-1040. 